\title{
A conservation conundrum: protecting bumble bees under the California Endangered Species Act
}

\author{
RICHARD G. HATFIELD ${ }^{1 *}$ AND SARINA JEPSEN ${ }^{1}$
}

\begin{abstract}
${ }^{1}$ The Xerces Society for Invertebrate Conservation, 628 NE Broadway, suite 200, Portland, OR 97221, USA
\end{abstract}

*Corresponding Author: rich.hatfield@xerces.org

Key words: Bumble bees, California Endangered Species Act, conservation, ecosystem services, insects, pollinators, policy

Bumble bees (Bombus spp., Apidae) are important pollinators throughout North America, and across the world. Their long tongues, ability to fly in low temperatures and inclement weather, as well as their aptitude at buzz pollination (Heinrich 2004) make them second only to the honey bee as pollinators that contribute to the multi-trillion dollar agricultural industry (Delaplane and Mayer 2000; Kremen et al. 2002; Klein et al. 2007; Gallai et al. 2009). In wildlands and natural areas, they are essential as generalist pollinators of many plant families (Goulson 2010). However, there have been alarming reports of bumble bee population declines from multiple continents (Cameron and Sadd 2020).

Notably, many species of bumble bees have been considered for listing as endangered species under the U.S. Endangered Species Act (ESA). The rusty patched bumble bee ( $B$. affinis), native to much of eastern North America, was added in 2017 (USFWS 2017). Franklin's bumble bee (B. franklini), native to a small portion of southern Oregon and northern California, was Proposed Endangered in 2019 (USFWS 2019a). The western bumble bee (B. occidentalis) and Suckley's cuckoo bumble bee (B. suckleyi) are both currently under review for ESA listing by the U.S. Fish and Wildlife Service (USFWS 2016). The yellow banded bumble bee (B. terricola) was evaluated for inclusion on the endangered species list, but ultimately deemed not warranted for listing by the Service (USFWS 2019b).

The specific causes of bumble bee declines are largely unknown, though several key threats have been identified. Pathogen infection (Cameron et al. 2016), insecticides (Wood and Goulson 2017), habitat loss (Williams and Osborne 2009), and climate change (Kerr et al. 2015) have all been individually identified as significant factors leading to observed declines. It is likely that each of these factors also interact, creating synergistic effects and accelerating declines (Cameron and Sadd 2020).

California is home to more than half (27) of the ca. 50 bumble bee species in North America - more than any other state in the country. Two of California's species, Franklin's bumble bee and Crotch's bumble bee (B. crotchii), are largely endemic; when they occur outside of California, it is within a short distance from the state's boundary. According to an analysis by the International Union for the Conservation of Nature (IUCN) Bumblebee 
Specialist Group, eight of California's bumble bees $(\sim 30 \%)$, including the two largely endemic species, are facing some degree of extinction risk (Hatfield et al. 2015a). Four of them are particularly imperiled, in need of rapid conservation action.

Crotch's bumble bee - Crotch's bumble bee historically occurred from the northern Central Valley to Baja Mexico, but has been lost from $70 \%$ of its range in California and now primarily persists in coastal southern California habitats, though also survives in a few areas around Sacramento (Fig. 1a; Hatfield et al. 2015b; NatureServe 2019; Richardson 2019; The Xerces Society et al. 2019). Crotch's bumble bee is a Species of Greatest Conservation Need (SGCN) in California (CDFW 2015), and is listed as endangered on the IUCN Red List (Hatfield et al. 2015b). SGCN status makes a species a target for conservation action, and eligible for conservation funding under the State Wildlife Action Plan.

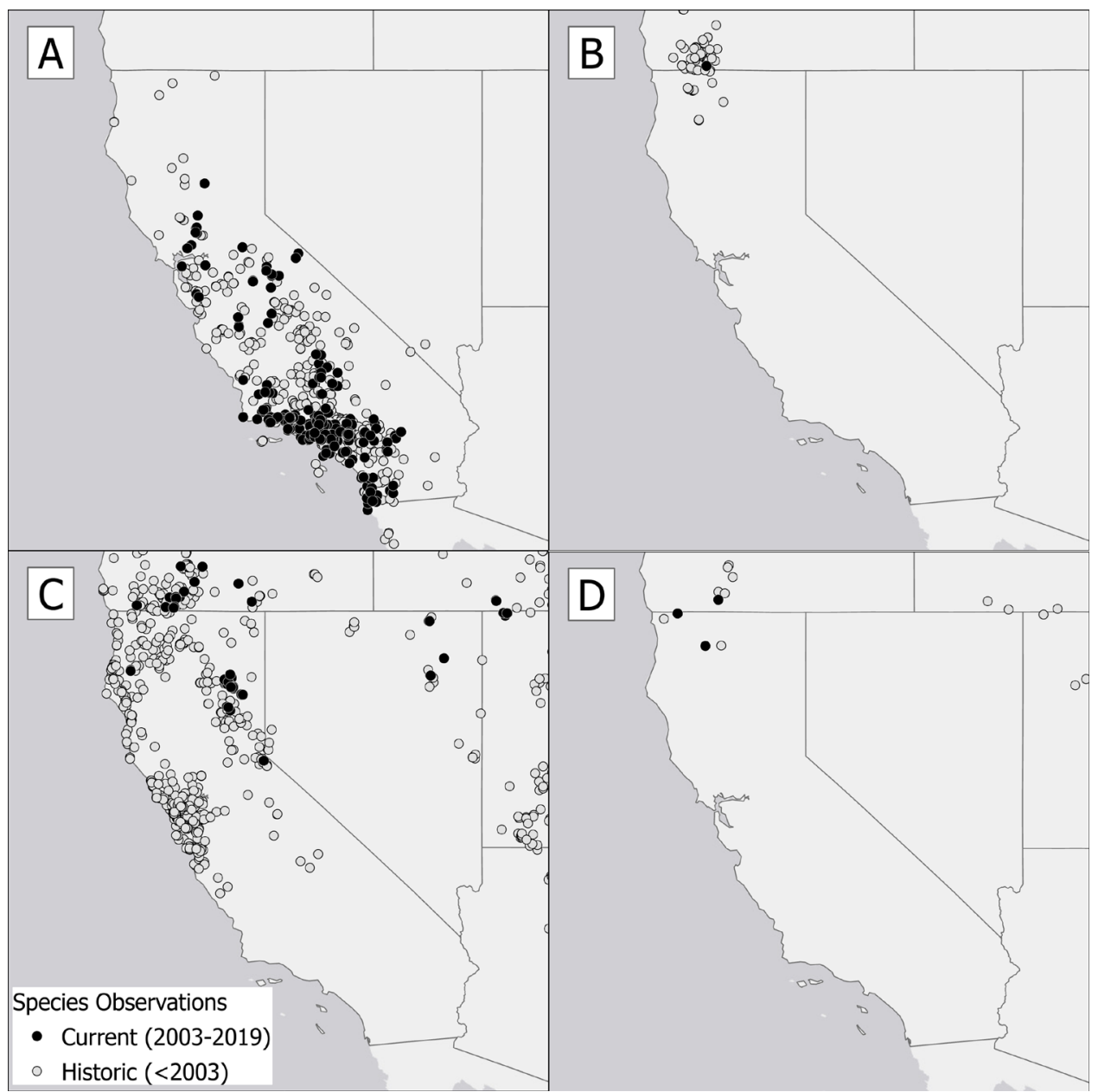

Figure 1. Current (filled circles, 2003-2019) and historic (open circles, before 2003) records of A) Crotch's bumble bee, B) Franklin's bumble bee, C) the western bumble bee, and D) Suckely's cuckoo bumble bee. Data from: Richardson 2019 and The Xerces Society et al. 2019. 
Franklin's bumble bee-Franklin's bumble bee has one of the smallest ranges of any bumble bee in the world in the Klamath-Siskiyou Mountains of southern Oregon and northern California. Its decline, which began in the late 1990s, was documented by Dr. Robbin Thorp who conducted annual surveys at historic sites and other nearby localities for this species from 1998-2017 (Thorp 1999, 2001, 2004, 2005a, 2005b). Despite extensive surveys by Dr. Thorp, the Bureau of Land Management (Code and Haney 2006), and the Service (J. Everett, U.S. Fish and Wildlife Service, personal communication), Franklin's bumble bee has not been detected since 2006 (Fig. 1b). Franklin's bumble bee is an SGCN in California (CDFW 2015).

The western bumble bee-The western bumble bee has experienced significant declines throughout its range, but most notably west of the Cascade/Sierra mountains, where observations are rare (Cameron et al. 2011; Hatfield et al. 2015c; Rhoades et al. 2016). Recent surveys from the Pacific Northwest Bumble Bee Atlas in Oregon, Washington, and Idaho have found that the western bumble bee's relative abundance has declined significantly throughout its former range in those states (Xerces Society et al. 2020) and has been lost from Pacific coastal areas of its historic range, experiencing an $80 \%$ decline in California (Fig. 1c; Unpublished analysis from Richardson 2019; The Xerces Society et al. 2019). These data are corroborated by a recent occupancy modeling analysis, which found that the probability of occupancy by the western bumble bee has declined by $93 \%$ over the last 21 years (Graves et al. 2020). The western bumble bee is an SGCN in California (CDFW 2015).

Suckley's cuckoo bumble bee-Suckley's cuckoo bumble bee is a social parasite that uses the western bumble bee as its host species; it has also been detected in the nests of other species (Thorp 1983; Williams et al. 2014). Since the western bumble bee has declined extensively, it is highly likely that this cuckoo bumble bee has experienced a parallel—and likely more serious - decline. This species is listed as Critically Endangered on the IUCN Red List (Hatfield et al. 2015d) and has not been detected in Pacific Northwest Bumble Bee Atlas surveys from Oregon, Washington, or Idaho to date (Xerces Society et al. 2020) and has been lost from 55\% of its range in California (Fig. 1d; Hatfield et al. 2015d; Unpublished analysis from Richardson 2019). Suckley's cuckoo bumble bee is an SGCN in California (CDFW 2015).

Recognizing that without formal protection it was likely that these four essential pollinators faced a high risk of extinction, in 2018 the Xerces Society, Defenders of Wildlife, and the Center for Food Safety filed a petition with the California Fish and Game Commission (FGC) asking the state to grant the western, Suckley's cuckoo, Crotch's, and Franklin's bumble bees protection under the California Endangered Species Act (CESA; Hatfield et al. 2018).

Protection under CESA would mediate threats and prevent these four species from going extinct, and likely provide corollary protection to a diversity of wild species that provide pollination services to crops (Kremen et al. 2002) and natural lands throughout the state. CESA protection would: (1) explicitly protect these bumble bees from take, including capturing or killing them (but see agricultural exemption below); (2) allow for the use of Safe Harbor Agreements to encourage landowners to manage their lands to benefit bumble bees, without subjecting them to additional regulatory restrictions because of their efforts; (3) encourage farmers and ranchers to establish programs to enhance and maintain habitat for bumble bees (Voluntary Local Program); and (4) foster the development of Habitat Conservation Plans (HCPs) and Natural Community Conservation Plans (NCCPs) with public and private stakeholders. 
In 2019, the California Department of Fish and Wildlife (CDFW) completed an initial review of the bumble bee petition and recommended that the FGC designate these bumble bees as Candidate Species, while CDFW conducted a more in-depth analysis of each species' status. On June 12, 2019, the FGC designated these four bumble bees as Candidate Species, affording them the full protections of listing under CESA until a final determination could be made. By early September, a lawsuit was filed against the FGC and CDFW by lawyers representing several large-scale agricultural groups, including the Almond Alliance of California, California Association of Pest Control Advisers, California Citrus Mutual, California Cotton Ginners and Growers Association, California Farm Bureau Federation, Western Agricultural Processors Association, and the Western Growers Association. The Xerces Society, Defenders of Wildlife, and Center for Food Safety joined the lawsuit as intervenors on behalf of the State, represented by Stanford Law School's Mills Legal Clinic (Superior Court of California 2019).

The California legislature passed a law in 1997 that exempts farmers from any liability associated with CESA, if and when they accidentally harm a protected (i.e. candidate, threatened, or endangered) species during the course of their routine farming practices (CA Fish \& G. Code $\S 2087$ ). This provision is currently set to expire in 2024, but this exemption has routinely been renewed by the legislature since its inception. In 1997, the legislature also authorized the creation of Voluntary Local Programs for farmers and ranchers that ensure they will not be penalized for accidentally harming endangered species if and when they proactively engage in conservation activities to benefit those species (CA Fish \& G. Code $\S 2086$ ).

Nevertheless, to establish standing in the lawsuit filed in September 2019, the consortium of agricultural groups claimed that protecting these bumble bees would interfere with their farming practices. The petitioners argued that the state of California did not have the legal authority to protect insects under CESA when they designated these four bumble bees as candidate species. They cited section 2062 of the Fish and Game Code, which states that an "'endangered species' means a native species or subspecies of a bird, mammal, fish, amphibian, reptile, or plant which is in serious danger of becoming extinct throughout all, or a significant portion, of its range..." (CA Fish \& G. Code $\S 2062$ ). However, the state legislature defined 'fish' broadly in the Fish and Game Code; Section 45 states that "'Fish' means a wild fish, mollusk, crustacean, invertebrate, amphibian, or part, spawn, or ovum of any of those animals" (CA Fish \& G. Code § 45).

In the definition of "fish," the state legislature did not qualify the type of invertebrates to be included (such as marine, freshwater, terrestrial; CA Fish \& G. Code $\S 45$ ). The legislature also included mollusks, crustaceans (both independently classified as invertebrates), and amphibians within its definition of "fish," and each of those animal groups contain many species that have no association with marine habitats. Indeed, three non-marine invertebrate species are already protected under CESA, the trinity bristle snail (Monadenia infumata setosa; which lives on land), and the Shasta crayfish (Pacifastacus fortis) and California freshwater shrimp (Syncaris pacifica), both of which live in freshwater habitats.

Since bumble bees are unquestionably invertebrates, the FGC and CDFW, as well as the intervenors, argued that the state has the authority to protect bumble bees under CESA and that it was the legislature's intent to protect insects under CESA when the law was passed in the early 1980s. However, Judge James P. Arguelles concluded that the legislature meant only marine invertebrates when it included invertebrates in the definition of fish, stating in the final ruling that "the word 'invertebrates' as it appears in Section 45's definition of 'fish' 
clearly denotes invertebrates connected to a marine habitat, not insects such as bumble bees." In February of 2021, the FGC and intervenors appealed this decision.

There is little question that protecting bumble bee diversity in the state of California benefits humans and native ecosystems, but the conservation of this resource particularly benefits the agricultural sector, which helps to feed the residents of the state. Indeed, as much as $35 \%$ of the food we eat comes from crops that are pollinated by bees (Klein et al. 2007). In agricultural systems, on average, wild pollinators contribute pollination services valued at $\$ 3,251$ per hectare to insect pollinated crops (including almonds) - the same value as that contributed by managed European honey bees (Kleijn et al. 2015). In Western North America, $50 \%$ of the wild bees contributing significantly to pollination services are bumble bees, and this service is valued at more than $\$ 480$ per hectare for insect pollinated crops (Kleijn et al. 2015). Wild bees also provide important insurance against the continued loss of managed honey bees, on which agricultural systems in California now depend (Winfree et al. 2007). Moreover, wild bees provide their pollination services for free, whereas the cost of honey bee pollination services can be expensive, often in excess of $\$ 100 /$ hive during the peak of almond bloom. Additionally, but not insignificantly, wild pollinators are largely responsible for maintaining plant diversity throughout California's ecosystems, on which most wildlife species depend.

Without state protection, bumble bee populations (and other wild pollinators) are likely to continue to decline throughout California, which could lead to increased agricultural dependence on managed pollinators. Some managed pollinators have been shown to compete with native bees for resources and to spread pathogens to wild bees, accelerating declines (Graystock et al. 2013, 2016; Fürst et al. 2014; Lindström et al. 2016; Cane \& Tepedino 2017). This cycle of dependence thus creates a vortex of decline that is unsustainable for agricultural systems and wild pollinators alike.

The ecosystem service of pollination is just one of the many valuable services that invertebrate animals provide. Native insects and other invertebrates play important roles in nutrient cycling and decomposition, pest control, and as food for other wildlife, like songbirds (Losey and Vaughan 2006). If CESA indeed excludes insects, not only does the law fail to protect ca. $80 \%$ of California's animal biodiversity, but also the ecosystem services they provide that are the fabric that holds our natural systems together (Wilson 1987). Article 1 of CESA states in relation to imperiled species: "These species of fish, wildlife, and plants are of ecological, educational, historical, recreational, esthetic, economic, and scientific value to the people of this state, and the conservation, protection, and enhancement of these species and their habitat is of statewide concern," giving broad authority to conserve species of value (CA Fish \& G. Code $\S 2051$ ). Excluding any insects from the law because of their taxonomic status significantly hampers CDFW and the FGC's ability to do so. Notably, other species that are valued by Californians and facing extinction, like the monarch butterfly (Danaus plexippus plexippus), may therefore be ineligible for protection by a law intended to safeguard wildlife in the state. Overwintering congregations of the western population of monarch butterflies, which occur only in coastal California, have declined by more than 99\% since the 1980s (Pelton et al. 2019). Without state protection, this iconic species is likely to be extirpated from California.

Despite the fact that the overwhelming majority of invertebrates are beneficial, contributing essential ecosystem services and billions of dollars to the global economy, the prevailing attitude toward them is disappointingly negative (Kellert 1993; Batt 2009), likely leading to the uncertainty surrounding their inclusion under CESA. Nevertheless, the 
charismatic nature of an animal should not seal its fate. We have now spent more than a year considering whether bumble bees can be included under the law, rather than investing that time developing practical solutions to benefit bumble bees and the fields they help pollinate.

\section{ACKNOWLEDGMENTS}

We would like to thank S.F. Jordan (Xerces Society), M. Blackburn (Xerces Society), and A. Code (Xerces Society), for their contributions to the petition asking the FGC to list the four bumble bees as endangered under CESA, and Defenders of Wildlife and the Center for Food Safety for their work to promote protection of these bumble bees under CESA. We would also like to thank the late Dr. R.W. Thorp (Professor Emeritus, UC Davis) for his tireless efforts to understand and conserve California's bumble bees. We are also grateful for the editorial comments and suggestions from several anonymous reviewers.

\section{LITERATURE CITED}

Batt S. 2009. Human attitudes towards animals in relation to species similarity to humans: a multivariate approach. Bioscience Horizons: The International Journal of Student Research 2:180-190.

California Department of Fish and Wildlife (CDFW). 2015. State Wildlife Action Plan. Species of Greatest Conservation Need. Vol II, Appendix C.

Cameron, S. A., H. C. Lim, J. D. Lozier, M. A. Duennes, and R. Thorp. 2016. Test of the invasive pathogen hypothesis of bumble bee decline in North America. Proceedings of the National Academy of Sciences 113:4386-4391.

Cameron, S. A., J. D. Lozier, J. P. Strange, J. B. Koch, N. Cordes, L. F. Solter, and T. L. Griswold. 2011. Patterns of widespread decline in North American bumble bees. Proceedings of the National Academy of Sciences 108:662-667.

Cameron, S. A., and B. M. Sadd. 2020. Global trends in bumble bee health. Annual Review of Entomology 65:209-232.

Cane, J. H., and V. J. Tepedino 2017. Gauging the effect of honey bee pollen collection on native bee communities: Apis pollen depletion and native bees. Conservation Letters 10:205-210.

Code, B. H., and S. L. Haney. 2006. Final Report: Franklin's Bumble Bee Inventory in the Southern Cascades of Oregon. Prepared for: The Bureau of Land Management, Medford, OR, USA.

Delaplane, K. S., and D. F. Mayer. 2000. Crop pollination by bees. Cabi Publishing, New York, NY, USA.

Fürst, M. A., D. P. McMahon, J. L. Osborne, R. J. Paxton, and M. J. F. Brown. 2014. Disease associations between honeybees and bumblebees as a threat to wild pollinators. Nature 506:364-366.

Gallai, N., J. M. Salles, J. Settele, and B. E. Vaissière. 2009. Economic valuation of the vulnerability of world agriculture confronted with pollinator decline. Ecological economics: the journal of the International Society for Ecological Economics 68:810-821.

Goulson, D. 2010. Bumblebees: Behavior, Ecology, and Conservation. Oxford University Press, Oxford, UK.

Graves, T. A., W. M. Janousek, S. M. Gaulke, A. C. Nicholas, D. A. Keinath, C. M. Bell, S. Cannings, R. G. Hatfield, J. M. Heron, J. B. Koch, H. L. Loffland, L. L. Rich- 
ardson, A. T. Rohde, J. Rykken, J. P. Strange, L. M. Tronstad, and C. S.Sheffield. 2020. Western bumble bee: declines in the continental United States and rangewide information gaps. Ecosphere 11:99.

Graystock, P., E. J. Blane, Q. S. McFrederick, and D. Goulson, WOH Hughes. 2016. Do managed bees drive parasite spread and emergence in wild bees? International Journal for Parasitology: Parasites and Wildlife 5:64-75.

Graystock, P., K. Yates, B. Darvill, D. Goulson, and W. O. H. Hughes. 2013. Emerging dangers: deadly effects of an emergent parasite in a new pollinator host. Journal of Invertebrate Pathology 114:114-119.

Hatfield, R. G., S. R. Colla, S. Jepsen, L. L. Richardson, R. W. Thorp, and S. Foltz-Jordan. 2015a. IUCN Assessments for North American Bombus spp. for the North American IUCN Bumble Bee Specialist Group. The Xerces Society for Invertebrate Conservation, Portland, OR, USA.

Hatfield, R., S. Jepsen, S. Foltz Jordan, M. Blackburn, and A. Code. 2018. A Petition to the State of California Fish and Game Commission to List the Crotch bumble bee (Bombus crotchii), Franklin's bumble bee (Bombus franklini), Suckley cuckoo bumble bee (Bombus suckleyi), and western bumble bee (Bombus occidentalis occidentalis) as Endangered under the California Endangered Species Act. The Xerces Society for Invertebrate Conservation, Portland, OR, USA.

Hatfield, R., S. Jepsen, R. W. Thorp, L. L. Richardson, and S Colla. 2015b. Crotch bumble bee, Bombus crotchii. IUCN Red List of Threatened Species 2015.1.

Hatfield, R., S. Jepsen, RW Thorp, L. L. Richardson, and S Colla. 2015c. Western bumble bee, Bombus occidentalis. IUCN Red List of Threatened Species 2015.1.

Hatfield, R., S. Jepsen, R. W. Thorp, L. L. Richardson, and S Colla. 2015d. Bombus suckleyi (Suckley Cuckoo Bumble Bee). IUCN Red List of Threatened Species 2015.1.

Heinrich, B. 2004. Bumblebee Economics. Harvard University Press, Cambridge, MA, USA.

Kellert, S. R. 1993. Values and perceptions of invertebrates. Conservation Biology 7:845855.

Kerr, J. T. A. Pindar, P. Galpern, L. Packer, S. G. Potts, S. M. Roberts, P. Rasmont, O. Schweiger, S. R. Colla, L. L. Richardson, D. L. Wagner, L. F. Gall, D. S. Sikes, and A. Pantoja. 2015. Climate change impacts on bumblebees converge across continents. Science 349:177-180.

Kleijn, D., R. Winfree, I. Bartomeus, L. G. Carvalheiro, M. Henry, R. Isaacs, A. Klein, C. Kremen, L. K. M'Gonigle, R. Rader, T. H. Ricketts, N. M. Williams, N. L. Adamson, J. S. Ascher, A. Báldi, P. Batáry, F. Benjamin, J. C. Biesmeijer, E. J. Blitzer, R. Bommarco, M. R. Brand, V. Bretagnolle, L. Button, D. P. Cariveau, R. Chifflet, J. F. Colville, B. N. Danforth, E. Elle, M. P. D. Garratt, F. Herzog, A. Holzschuh, B. G. Howlett, F. Jauker, S. Jha, E. Knop, K. M. Krewenka, V. Le Féon, Y. Mandelik, E. A. May, M. G. Park, G. Pisanty, M. Reemer, V. Riedinger, O. Rollin, M. Rundlöf, H. S. Sardiñas, J. Scheper, A. R. Sciligo, H. G. Smith, I. Steffan-Dewenter, R. Thorp, T. Tscharntke, J. Verhulst, B. F. Viana, B. E. Vaissière, R. Veldtman, K. L. Ward, C. Westphal, and S. G. Potts. 2015. Delivery of crop pollination services is an insufficient argument for wild pollinator conservation. Nature Communications 6:7414.

Klein, A. M., B. E. Vaissiere, J. H. Cane, I. Steffan-Dewenter, S. A. Cunningham, C. Kremen, and T. Tscharntke. 2007. Importance of pollinators in changing landscapes 
for world crops. Proceedings of the Royal Society B 274:303.

Kremen, C., N. M. Williams, and R. W. Thorp. 2002. Crop Pollination from Native Bees at Risk from Agricultural Intensification. Proceedings of the National Academy of Sciences of the United States of America 99:16812-16816.

Lindström, S. A. M., L. Herbertsson, M. Rundlöf, R. Bommarco, and H. G. Smith. 2016. Experimental evidence that honeybees depress wild insect densities in a flowering crop. Proceedings of the Royal Society B 283:1641.

Losey, J. E., and M. Vaughan. 2006. The economic value of ecological services provided by insects. Bioscience 56:311-323.

NatureServe. 2019. Comprehensive Report Species - Bombus crotchii. Available from: http://explorer.natureserve.org/servlet/NatureServe?searchName=Bombus + crotc hii (Accessed: 6 March 2020).

Pelton, E. M., C. B. Schultz, S. J. Jepsen, S. H. Black, and E. E. Crone. 2019. Western Monarch Population Plummets: Status, Probable Causes, and Recommended Conservation Actions. Frontiers in Ecology and Evolution 7:258.

Rhoades, P. R., J. B. Koch, L. P. Waits, J. P. Strange, and S. D. Eigenbrode. 2016. Evidence for Bombus occidentalis (Hymenoptera: Apidae) Populations in the Olympic Peninsula, the Palouse Prairie, and Forests of Northern Idaho. Journal of Insect Science 16.

Richardson, L. L. 2019. Bumble Bees of North America: Data Contributors. Available from: http://www.leifrichardson.org/bbna.html (Accessed: 24 January 2020).

Superior Court of California. 2019. Almond Alliance of California; California Association of Pest Control Advisers; California Citrus Mutual; California Cotton Ginners and Growers Association; California Farm Bureau Federation; Western Agricultural Processors Association; and Western Growers Association, Petitioners/Plaintiffs, v. California Fish and Game Commission, a California Public Agency; California Department of Fish and Wildlife, a California Public Agency, Respondents/ Defendants, Xerces Society for Invertebrate Conservation; Defenders of Wildlife; and Center for Food Safety, Intervenors, No. 34-2019-80003216 (Superior Court of California Filed: September 9, 2019).

Thorp, R. W., D. S. Horning, and L. L. Dunning. 1983. Bumble bees and cuckoo bumble bees of California (Hymenoptera, Apidae). Volume 23. University of California Press, Berkeley, CA, USA.

Thorp, R. W. 1999. Franklin's bumble bee, Bombus franklini (Frison 1921): a species of special concern. Report to USDA Forest Service, Ashland, OR, USA.

Thorp, R.W. 2001. Franklin's bumble bee, Bombus franklini (Frison 1921): a species of special concern. Report to US Fish and Wildlife Service, Portland, OR, USA.

Thorp, R. W. 2004. Franklin's bumble bee, Bombus franklini (Frison 1921): a species of special concern. Report to US Fish and Wildlife Service, Portland, OR, USA.

Thorp, R. W. 2005a. Franklin's bumble bee, Bombus franklini (Frison 1921): a species of special concern. Report to US Fish and Wildlife Service, Portland, OR, USA.

Thorp, R. W. 2005b. Franklin's bumble bee, Bombus franklini (Frison 1921): a species of special concern. Report to US Fish and Wildlife Service, Portland, OR, USA.

U.S. Fish and Wildlife Service (USFWS). 2016. Endangered and Threatened Wildlife and Plants; 90-Day Findings on 29 Petitions. Federal Register 81:14058-14072.

U.S. Fish and Wildlife Service (USFWS). 2017. Endangered and Threatened Wildlife and 
Plants; Endangered Species Status for Rusty Patched Bumble Bee. Federal Register 82:3186-3209.

U.S. Fish and Wildlife Service (USFWS). 2019a. Endangered and Threatened Wildlife and Plants; Endangered Species Status for Franklin's Bumble Bee (Bombus franklini). Federal Register 84:40006-40019.

U.S. Fish and Wildlife Service (USFWS). 2019b, August 15. Endangered and Threatened Wildlife and Plants; 12-Month Findings on Petitions to List Eight Species as Endangered or Threatened Species. Federal Register 84:41694-41699.

Williams, P. H., and J. L. Osborne. 2009. Bumblebee vulnerability and conservation worldwide. Apidologie 40:367-387.

Williams, P. H, R. Thorp, L. L. Richardson, and S. R. Colla. 2014. Bumble Bees of North America: An Identification Guide: An Identification Guide. Princeton University Press. Princeton, NJ, USA.

Wilson, E. O. 1987. The little things that run the world (the importance and conservation of invertebrates). Conservation Biology 1:344-346.

Winfree, R., N. M. Williams, J. Dushoff, and C. Kremen. 2007. Native bees provide insurance against ongoing honeybee losses. Ecology letters 10:1105-1113.

Wood, T. J., and D. Goulson. 2017. The environmental risks of neonicotinoid pesticides: a review of the evidence post 2013. Environmental Science and Pollution Research International 24:17285-17325.

The Xerces Society, Idaho Fish and Game, and Washington Department of Fish and Wildlife. 2020. The Pacific Northwest Bumble Bee Atlas: PNWBumbleBeeAtlas.org, Data accessed from Bumble Bee Watch. Available from: http://www.bumblebeewatch.org/app/\#/bees/lists. (Accessed: 23 October 2020).

The Xerces Society, Wildlife Preservation Canada, York University, The Montreal Insectarium, The London Natural History Museum, and BeeSpotter. 2019. Data accessed from Bumble Bee Watch, a collaborative website to track and conserve North America's bumble bees. Available from: http://www.bumblebeewatch.org/app/\#/ bees/lists (Accessed: September 5, 2019).

Submitted 1 December 2020

Accepted 22 January 2021

Associate Editor was R. La Rosa 